\title{
Peningkatan Kualitas Pelayanan Aparatur Pemerintah Kelurahan Limo Depok
}

\author{
Dewi Cahyani Pengestuti ${ }^{1}$, Renny Husniaty ${ }^{2}$ \\ 1,2Universitas Pembangunan Nasional “Veteran" Jakarta \\ Email: 1dewichepe@upnvj.ac.id, 2rennyhusniaty@gmail.com
}

\begin{abstract}
Abstrak
Kelurahan sebagai wilayah administrasi publik yang merupakan ujung tombak pemerintahan, berkewajiban memenuhi kebutuhan dan hak bagi setiap warga negara dalam bentuk layanan sipil yang tersedia hanya di kantor pemerintahan. Pada kenyataanya unit kerja tersebut masih belum optimal dalam melakukan tugas dan fungsinya khususnya dalam memberikan pelayanan terhadap masyarakat. Tujuan pengabdian pada masyarakat ini yaitu memberikan pelatihan yang dapat meningkatkan kualitas pelayanan aparat Kelurahan Limo, dengan meningkatkan kemampuan untuk menguasai ilmu pengetahuan dan teknologi, agar pelaksanaan pelayanan kepada masyarakat dapat tercapai secepat mungkin dengan mudah dan biaya murah dengan mengutamakan kepentingan dan kebutuhan masyarakat. Metode yang digunakan yaitu deskriptif dengan pendekatan kualitatif dengan pengumpulan data, baik dengan wawancara, observasi, dan dokumentasi. Pengabdian masyarakat ini dilaksanakan dua kali yaitu pada bulan November 2019 dan Januari 2020 di kantor Kelurahan Limo dengan memberikan pelatihan peningkatan kualitas pelayanan. Hasil dari pengabdian masyarakat ini, diharapkan ada peningkatan pelayanan yang meliputi 6 indikator kualitas pelayanan, yaitu: ketepatan waktu pelayanan, akurasi pelayanan, kesopanan dan keramahan dalam memberikan pelayanan, kemudahan dalam mendapatkan pelayanan, kenyamanan dalam peroleh pelayanan dan atribut pendukung lainnya seperti sarana prasarana. Sesuai dengan hasil pengabdian di lapangan dari ke enam indikator yang menentukan kualitas pelayanan yang dijadikan tolok ukur untuk mengevaluasi kualitas pelayanan publik agar memenuhi kepuasan masyarakat, maka masih banyak hal yang harus dibenahi dalam rangka peningkatan kualitas pelayanan kepada masyarakat. Saran yang dapat disampaikan yaitu perlu peningkatan disiplin pegawai, perlu adanya bimbingan dan pelatihan yang terus-menerus serta perlu pembenahan dan penambahan beberapa fasilitas kantor untuk menunjang kelancaran aktivitas pelayanan.
\end{abstract}

Kata Kunci: Kualitas Pelayanan Publik, Aparat Kelurahan

\section{Abstract}

Sub District as territoryadministration public that is the end spear government. Obliged to fulfil needs and right for each citizen's country in shape service civil which are available only in government offices. In fact a work unit the still not optimal in doing the job and function especially in giving service to the community. Destination this community service is to provide training that can improve the quality of service for the Limo Village apparatus, by improving ability to dominate science knowledge and technology, so that implementation of 
services to Public could reached as fast as maybe with easy and low cost by prioritizing the interests and needs of the community. The method used is descriptive with approach qualitative data collection, either by interview, observation, and documentation. This community service was carried out twice, in November 2019 and January 2020 at the Limo Village office by providing training to improve service quality. As a result of this community service, it is hoped that there will be an increase in service which includes 6 indicators of service quality : accuracy service time, service accuracy, courtesy and friendliness in give service, convenience in getting service, comfort inget itservice and other supporting attributes such as infrastructure. In accordance with the results of the service in the field from the six indicators that determine quality service that made benchmarks to evaluate quality of public services in order meet satisfaction community, there are still many things that must be addressed in order to improve the quality of services to the community. Suggestions that can be conveyed are the need to improve employee discipline, continuous guidance and training and need to improve and add some office facilities to support the smooth running of service activities.

Keywords : Quality Of Public Services, Village Officials

\section{Pendahuluan}

Searah dengan meningkatnya era globalisasi dan arus informasi yang cepat mengakibatkan tugas dan tanggung jawab pemerintah kian rumit, baik dalam mutu ataupun kuantitasnya. Proses ini menuntut aparatur pemerintah mempunyai performa yang lebih baik sehingga bisa memberikan pelayanan pada masyarakat. Peningkatan dan tuntutan masyarakat akan pelayanan publik yang tepat sasaran, efisien serta memuaskan dari pegawai pemerintah sebagai pelayan publik kian populer. Hal ini berhubungan dengan perkembangan kebutuhan, harapan dan keinginan masyarakat yang terus bertambah dan kian mutakhir (Gamal, 2018). Masyarakat sebagai subjek layanan tak menyukai lagi dengan pelayanan yang berbelit-belit, lama dan beresiko dampak rantai birokrasi yang panjang. syarakat menghendaki kesegaran pelayanan, sekaligus mampu memahami kebutuhan dan keinginan yang terpenuh dalam waktu yang relatif singkat (Pertiwi et al.,2017). Keinginan-keinginan tersebut Perlu direspon dan dipenuhi oleh instansi yang bergerak dalam bidang jasa, apabila aktivitasnya ingin memiliki citra yang baik, untuk itu pihak manajemen perlu mengevaluasi kembali aspek pelayanan yang selama ini diberikan apakah telah sesuai dengan kebutuhan dan keinginan masyarakat yang dilayani, atau justru sebaliknya masih terdapat kesenjangan antara pelayanan yang diberikan dengan pelayanan yang diharapkan masyarakat. Terjadinya kesenjangan menunjukkan adanya kualitas pelayanan yang kurang prima, sehingga berpotensi menurunkan kinerja instansi secara keseluruhan (Kusuma \& Suflani, 2019).

Aparatur pemerintah kelurahan sebagai Pegawai Negeri Sipil acapkali diberikan predikat sebagai abdinegara dan abdi masyarakat atau pelayan masyarakat. Pemerintah merupakan pemegang kekuasaan, dan dalam suatu negara demokrasi 
kekuasaan itu bersumber pada rakyat. Hal ini berarti pemerintah melayani rakyat untuk memenuhi kebutuhan tersebut. Aparatur pemerintah kelurahan perlu dibekali kecakapan untuk menguasai ilmu pengetahuan dan teknologi, supaya pelaksanaan pelayanan kepada masyarakat dapat tercapai secepat mungkin dengan gampang dan biaya murah (Purwadi, 2019). Permasalahan peningkatan pelayanan tergantung pada kemampuan sumber daya manusia aparatur pemerintah kelurahan dan jumlah aparatur yang melayani. Untuk menetapkan keberhasilan pemerintah kelurahan dalam memberikan pelayanan, ialah dengan melihat rasio atau komposisi perangkat setiap urusan dalam memberikan pelayanan dengan jumlah pendudukyang seharusnya diberikan pelayanan (Spears \& Lawrence, 2016).

Pemerintah Kelurahan sebagai wilayah administrasi publik yang merupakan ujung tombak pemerintahan, berkewajiban memenuhi kebutuhan dan hak bagi setiap warga negara dalam bentuk layanan sipil yang tersedia hanya di kantor pemerintahan, (Bawole et al., 2015). Pada kenyataanya unit kerja tersebut masih belum optimal dalam melakukan tugas dan fungsinya khususnya dalam memberikan pelayanan terhadap masyarakat. Masalah utama pelayanan publik sebetulnya ialah peningkatan mutu pelayanan publik itu sendiri (Gamal, 2018). Pelayanan publik yang berkualitas dipengaruhi oleh berbagai aspek, yaitu bagaimana pola penyelenggaraannya, sumber daya manusia yang mendukung dan kelembagaan. Beberapa kelemahan pelayanan publik berhubungan dengan pola penyelenggaraannya antara lain (Mahsyar, 20), (Maryam, 2016):

1. Sukar Diakses. Unit pelaksana pelayanan publik berlokasi jauh dari jangkauan masyarakat, sehingga mempersulit masyarakat yang membutuhkan pelayanan publik tersebut.

2. Belum informatif. Biasanya informasi yang disampaikan kepada masyarakat cenderung lambat ataubahkan tidak diterima oleh masyarakat.

3. Belum bersedia mendengar keluhan atau saran atau aspirasi masyarakat. Biasanya aparat pelayanan publik belum bersedia mendengar keluhan atau saran atau aspirasi dari masyarakat. Sehingga, pelayanan publik dilaksanakan semau sendiri dan sekedarnya, tanpa ada perbaikan dari waktu ke waktu.

4. Belum responsif. Hal ini terjadi pada hamper seluruh tingkatan unsur pelayanan publik, mulai pada tingkatan petugas pelayanan hingga jenjang penanggungjawab instansi. Tanggapan terhadap berbagai keluhan, aspirasi, maupun harapan masyarakat seringkali lambat atau pun malah tak dihiraukan sama sekali.

5. Belum saling berkoordinasi. Setiap unit pelayanan yang terkait satu dengan lainnya belum saling berkoordinasi. Dampaknya, sering terjadi tumpeng tindih maupun pertentangan kebijakan antara satu instansi pelayanan dengan instansi pelayanan lain yang berterkaitan.

6. Birokrasi yang bertele-tele. Pelayanan (terutama pelayanan perijinan) biasanya dilaksanakan melalui proses yang terdiri dari berbagai tahapan, sehingga menyebabkan penyelesaian pelayanan yang terlalu lama. 
Berdasarkan uraian yang telah dikemukakan di atas maka tujuan kegiatan pengabdian kepada masyarakat ini yaitu memberikan pelatihan yang dapat meningkatkan kualitas pelayanan aparat Kelurahan Limo, dengan meningkatkan kemampuan untuk menguasai ilmu pengetahuan dan teknologi, agar pelaksanaan pelayanan kepada masyarakat dapat tercapai secepat mungkin dengan mudah dan biaya murah dengan mengutamakan kepentingan dan kebutuhan masyarakat, (Malik, 2018).

\section{Metode}

Sasaran kegiatan pengabdian masyarakat ini adalah aparat/pegawai di Kelurahan Limo Depok. Kegiatan pengabdian ini menggunakan metode deskriptif dengan pendekatan kualitatif dengan pengumpulan data, baik dengan wawancara, observasi, dan dokumentasi, (Wahid, 2017). Adapun penentuan materi berdasarkan masukan yang didapat dari hasil survey pertama (September 2019). Dalam kegiatan ini, pelaksanaan dilakukan selama 2 (dua) kali pada bulan November 2019 dan Januari 2020 bertempatan di kantor Kelurahan Limo. Bulan November 2019 pengabdi melakukan pre tes untuk mengetahui sejauhmana pemahaman aparat kelurahan Limo terhadap kualitas pelayanan yang diberikan selama ini dan dilanjutkan dengan memberikan materi. Pada bulan Januari 2020, pengabdi kembali ke Kelurahan Limo untuk melihat apakah ada perubahan terhadap kualitas pelayanan dengan melakukan pengamatan, wawancara, serta melakukan post test untuk mengetahui sejauh mana pemahaman aparat kelurahan terhadap materi yang telah disampaikan terkait kualitas pelayanan dan apakah sudah ada peningkatan kualitas pelayanan. Adapun tahapan-tahapan yang dilaksanakan yaitu:

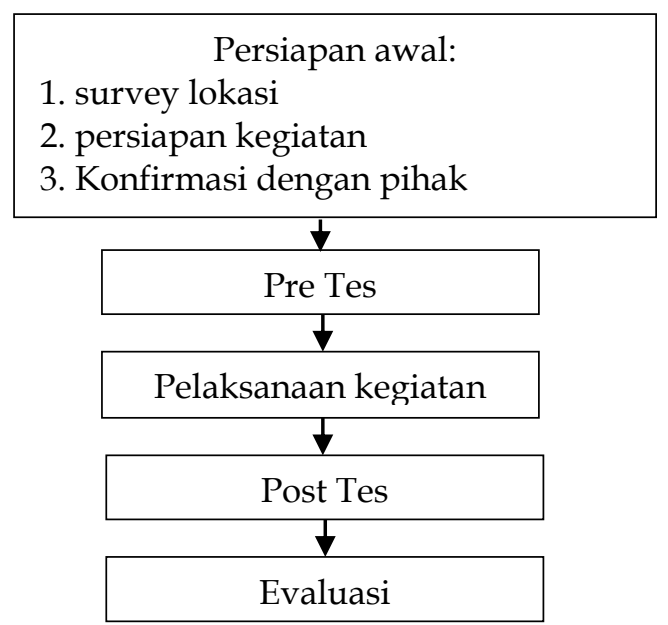

Gambar 1. Bagan Alir Pelaksanaan PKM Aparat Kelurahan Limo

1. Tim pengabdian melakukan survey lokasi pada bulan September 2019.

2. Persiapan kegiatan yang dilaksanakan oleh tim pengabdian untuk merencanakan kegiatan yang mencakup waktu, materi dan teknispelaksanaan kegiatan.

3. Konfirmasi dengan pihak Kelurahan, sebagai tempat pelaksanaan kegiatan mengenai teknis pelaksanaan, tempat, sarana dan prasarana.

4. Setelah diperoleh kepastian waktu dant empat pelaksanaan, tim pengabdian melakukan kegiatan wawancara kepada Staf Kelurahan Limo, dan memberikan 
pretest untuk mengetahui sejauh mana pemahaman aparat kelurahan Limo terhadap kualitas pelayanan yang diberikan selama ini dan mencari tahu pendapat masyarakat setempat mengenai pelayanan di Kelurahan Limo dengan memberikan kuesioner pelayanan aparat kelurahan Limo.

5. Pelaksanaan pelatihan Pelayanan Publik. Metode yang digunakan adalah metode ceramah untuk memberikan pemahaman tentang bagaimana Pelayanan Publik yang baik untuk masyarakat. Pelatihan memberikan pengetahuan dan pemahaman tentang pengertian dan konsep Pelayanan Publik yang baik. Selain itu, metode ini juga digunakan untuk mengenalkan bagaimana mengimplementasikan teori Pelayanan Publik. Selanjutnya dalam pelatihan ini peserta diajak berdiskusi dan melakukan tanya jawab. Adapun pengetahuan mengenai kualitas pelayanan yang meliputi:

a. Ketepatan waktu pelayanan, yang meliputi waktu tunggu dan waktu proses.

b. Akurasi pelayanan, yang meliputi bebas dari kekeliruan-kekeliruan.

c. Kesopanan dan keramahan dalam memberikan pelayanan kepada masyarakat.

d. Kemudahan dalam mendapatkan pelayanan, misalnya banyaknya petugas yang melayani dan banyaknya fasilitas pendukung seperti komputer.

e. Kenyamanan dalam memperoleh pelayanan, yang berkaitan dengan lokasi, ruang tempat pelayanan, tempat parkir, ketersediaan informasi dan lain-lain.

f. Atribut pendukung lainnya seperti ruang tunggu ber AC, toilet umum, kebersihan, dan lain-lain.

6. Post test untuk mengetahui sejauhmana pemahaman aparat kelurahan terhadap materi yang telah disampaikan terkait kualitas pelayanan.

7. Melakukan penyebaran kuesioner kepada masyarakat terkait pelayanan aparat kelurahan Limo setelah memperoleh pelatihan, yang dilaksanakan pada bulan Januari 2020.

\section{Hasil dan Pembahasan}

Pelayanan publik yakni suatu aktivitas yang melibatkan minimal dua orang yakni pihak yang dilayani dan pihak yang melayani. Ditinjau dari pelaksanannya, maka dalam pelayanan publik terjadi interaksi antara yang memberikan pelayanan dengan yang mendapatkan pelayanan. Dalam rangka menciptakan interaksi yang saling menguntungkan dalam penyelenggaraan pelayanan, karenanya dibutuhkan tindakan yang dalam teori dikenal dengan manajemen kualitas pelayanan, (Ugaddan \& Park, 2017).

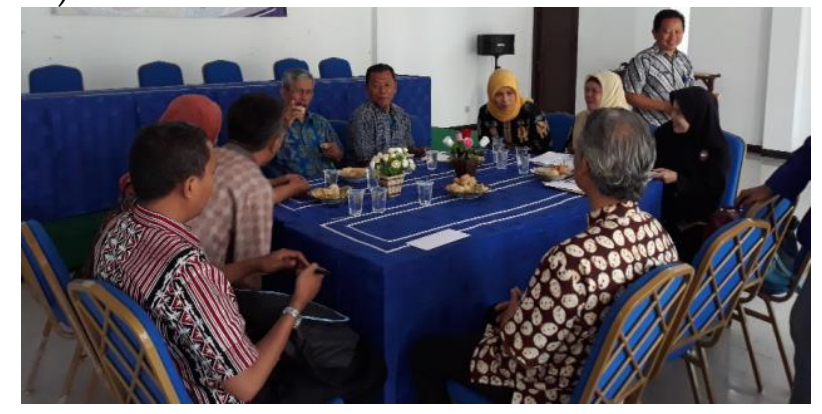

Gambar 2. Pemberian Pelatihan Bagi Aparat Kelurahan Limo 
Sehubungan dengan kualitas pelayanan, secara teoritis (Bawole et al., 2015) menjelaskan bahwa terdapat 6 faktor yang menentukan kualitas pelayanan publik, yaitu:

\section{Ketepatan Waktu Pelayanan}

Ketepatan waktu aparat kelurahan dalam memberikan pelayanan terhadap masyarakat di Kantor Kelurahan Limo amat penting, karena kesuksesan dalam memberikan pelayanan terhadap masyarakat seharusnya didukung dengan disiplin pegawai. Sesuai hasil pengabdian di Kantor Kelurahan Limo, pengabdi mengamati kegiatan pelayanan kerap terlambat dimulai atau tidak tepat waktu dari waktu yang sudah ditetapkan, hal ini disebabkan disiplin pegawai Kelurahan Limo masih terlihat relatif rendah. Ketentuan jam kerja pegawai dimulai pukul 07.30 tetapi masih ada pegawai yang masuk kerja pukul 08.00 atau lebih. Hal ini membuat masyarakat yang membutuhkan pelayananharusmenunggu beberapa waktu lagi. Hal ini terlihat dari hasil kuesioner yang diberikan kepada warga masyarakat yang menggunakan layanan Kelurahan Limo seperti pada histogram berikut ini:

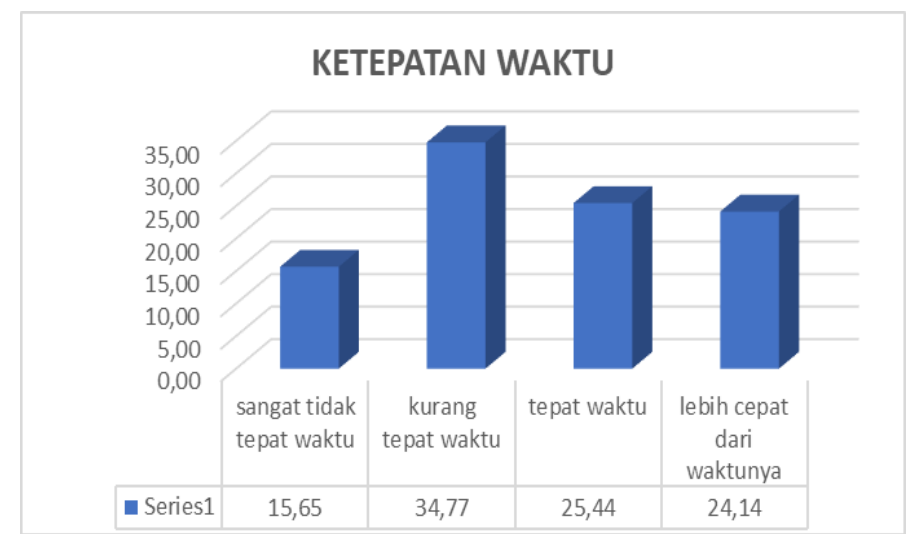

Gambar 3. Indikator Ketepatan Waktu Pelayanan Sebelum Pelatihan

Setelah pengabdi memberikan materi mengenai pelayanan kepada aparat Kelurahan Limo, maka ada perubahan yang cukup berarti terkait dengan ketepatan waktu pelayanan yang berhubungan dengan waktu proses pelayanan yang diberikan kepada masyarakat, sesuai dengan hasil pengamatan pengabdi di Kantor Kelurahan Limo, pengabdi melihat bahwa ketepatan waktu proses pelayanan petugas/aparat dalam melayani masyarakat setelah mengikuti pelatihan ini menjadi cukup baik. Aparat yang ada di kantorKelurahan Limo Sebagian besar sudah datang tepat waktu pukul 07.30 dan terlihat siap untuk membantu kebutuhan masyarakat, sepanjang persyaratan yang dibutuhkan telah lengkap. Ketepatan waktu untuk memproses kebutuhan masyarakat ini dinilai cukup baik. Petugas di Kantor Kelurahan Limo telah menunjukan dedikasi dan pengabdian yang baik dalam hal melayani masyarakat. Dari keseluruhan uraian di atas, maka pengabdi dapat menarik kesimpulan bahwa, kualitas pelayanan di Kantor Kelurahan Limo setelah mengikuti pelatihan ini dilihat dari sisi ketepatan waktu pelayanan sudah relatif baik, hanya dari sisi waktu tunggu pelayanan masih perlu ditingkatkan terutama masalah disiplin pegawai. 


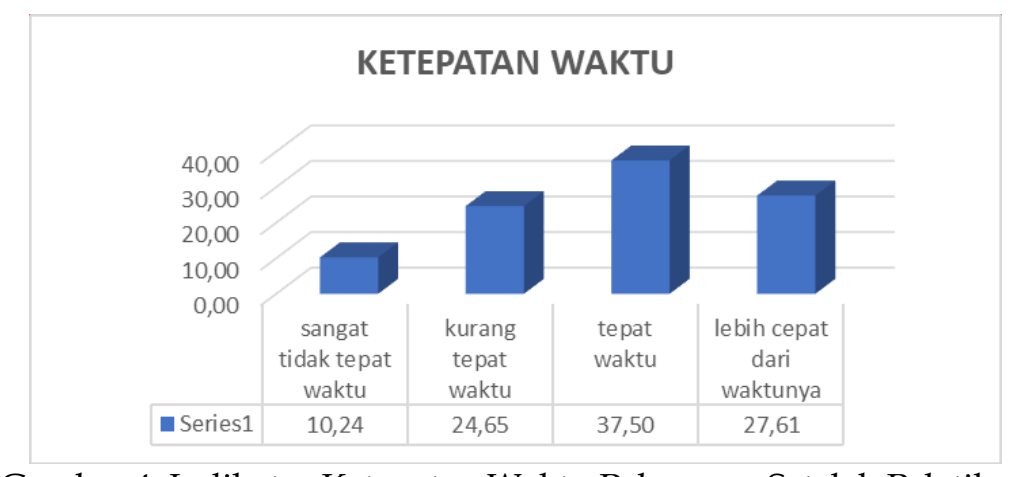

Gambar 4. Indikator Ketepatan Waktu Pelayanan Setelah Pelatihan

Dari gambar 3 dan 4 terlihat bahwa indikator ketepatan waktu pelayanan aparat Kelurahan Limo mengalami peningkatan setelah mengikuti pelatihan dan hal ini sesuai dengan harapan masyarakat.

\section{Akurasi Pelayanan}

Akurasi dalam hal memberikan pelayanan yang dimaksud ialah melakukan pelayanan terbebas dari kekeliruan-kekeliruan, (Purwadi, 2019). Permasalahan ini memang seharusnya menjadi perhatian yang sungguh-sungguh oleh aparat kelurahan Limo supaya pelayanan yang diterima masyarakat sesuai dengan keinginannya. Jikalau hal ini terjadi maka, aparat kelurahan seharusnya segera menaggapi supaya tidak menimbulkan permasalahan dan kekecewaan masyarakat. Sesuai hasil pengabdian di Kantor Kelurahan Limo, pengabdi melihat bahwa dalam pelayanan pegawai di kantor Kelurahan Limo masih sering terjadi kekeliruankekeliruan. Persoalan yang acapkali terjadi dalam hal pelayanan di Kelurahan Limo ialah faktor ketidaktelitian aparat kelurahan dalam hal mengatasi urusan masyarakat. Hal ini terlihat dari hasil kuesioner yang diberikan kepada warga masyarakat yang menggunakan layanan Kelurahan Limo seperti pada histogram berikut ini:

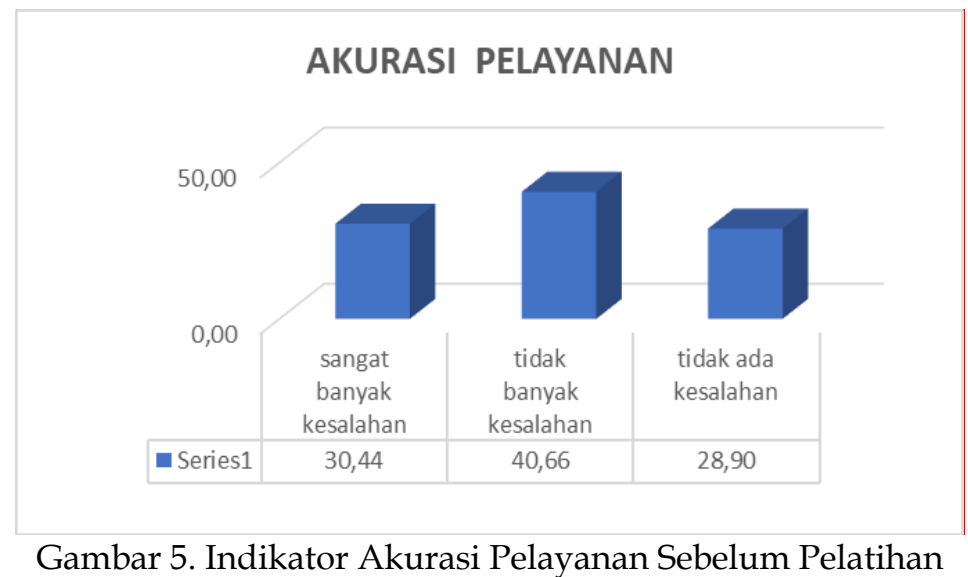

Setelah pengabdi memberikan materi mengenai pelayanan kepada aparat Kelurahan Limo, maka ada perubahan yang cukup berarti berkaitan dengan akurasi pelayanan. Pegawai di kantor Kelurahan Limo terlihat lebih hati-hati dan teliti serta memperhatikan SOP yang ada untuk mengurangi risiko kesalahan yang terjadi. Dan warga masyarakat merasa puas dengan hasil kinerja pegawai Kelurahan Limo. 


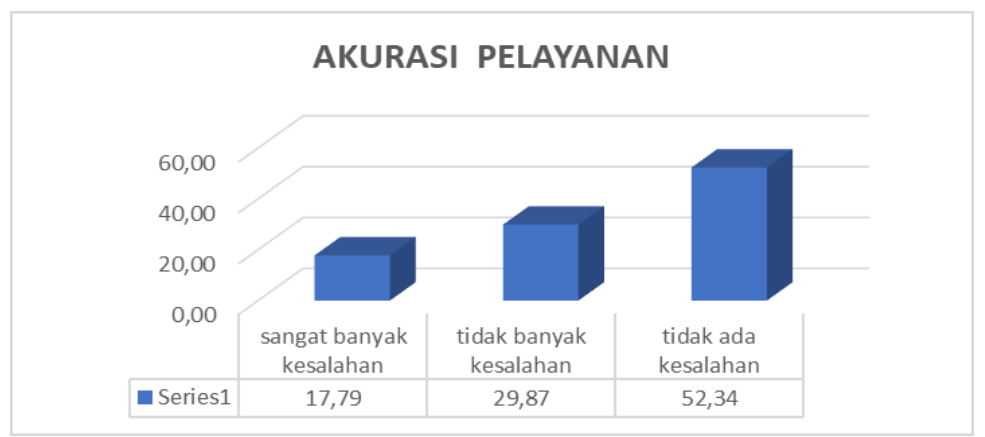

Gambar 6. Indikator Akurasi Pelayanan Setelah Pelatihan

Dari gambar 5 dan 6 terlihat bahwa indikator akurasi pelayanan aparat Kelurahan Limo mengalami peningkatan setelah mengikuti pelatihan, mereka lebih berhati hati dan teliti dalam melaksanakan tugas sehingga mengurangi tingkat kesalahankesalahan yang terjadi dan hal ini sesuai dengan harapan masyarakat yang tercermin dari hasil jawaban kuesioner yang dibagikan kepada warga masyarakat.

\section{Kesopanan dan Keramahan}

Kesopanan dan keramahan petugas, yakni sikap dan perilaku pegawai dalam memberikan pelayanan terhadap masyarakat secara sopan, santun dan ramah serta saling menghargai dan menghormati. Sehubungan dengan hal diatas, yang seharusnya diperhatikan dalam perbaikan mutu pelayanan antara lain kesopanan dan keramahan dalam memberikan pelayanan terutama saat terjadi interaksi langsung, (Safira, 2020).

Terkait dengan kesopanan dan keramahan pegawai dalam memberikan pelayanan terhadap masyarakat, sesuai dengan hasil pengabdian di Kantor Kelurahan Limo pengabdi melihat bahwa aparat kelurahan sudah cukup sopan dan ramah dalam memberikan pelayanan kepada masyarakat. Dan dengan pelatihan peningkatan kualitas pelayanan ini, maka sikap dan perilaku pegawai Kelurahan Limo semakin ramah dan sopan dalam memberikan pelayanan kepada warga masyarakat. Hal ini terlihat dari hasil jawaban responden yaitu warga masyarakat dalam menilai kesopanan dan keramahan pelayanan aparat Kelurahan Limo.

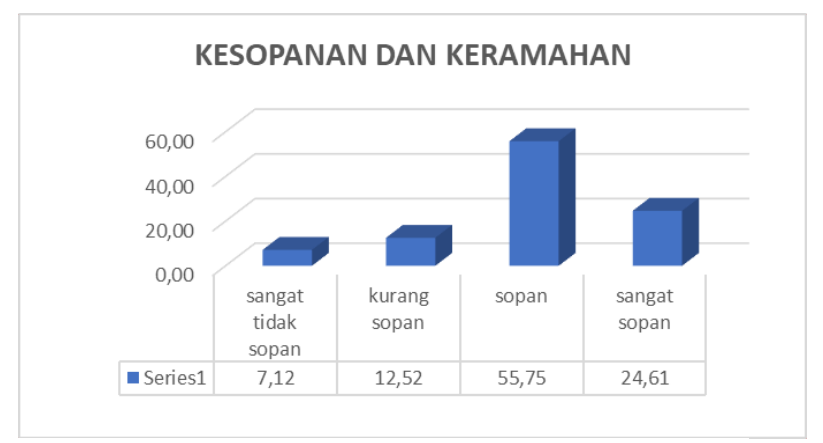

Gambar 7. Indikator Kesopanan dan Keramahan Sebelum Pelatihan

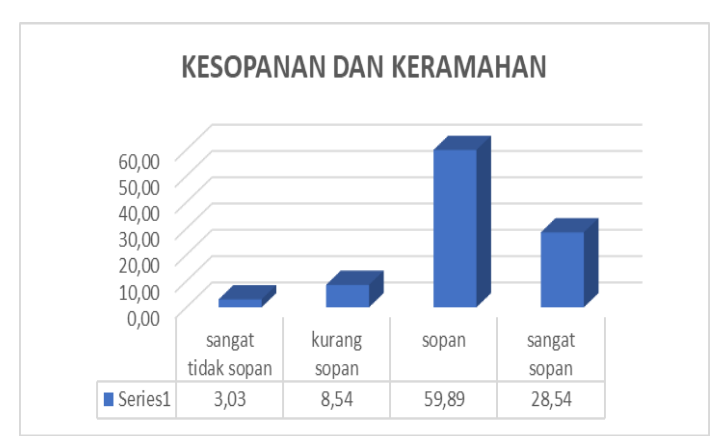

Gambar 8. Indikator Kesopanan dan Keramahan Setelah Pelatihan

Dari gambar 7 dan 8 terlihat bahwa indikator kesopanan dan keramahan aparat Kelurahan Limo mengalami peningkatan setelah mengikuti pelatihan, dimana sebetulnya aparat Kelurahan Limo sudah memiliki sikap sopan dan ramah kepada 
masyarakat yang mendapatkan pelayanan. Kondisi ini terlihat dari suasana keakraban antara aparat kelurahan dengan warga masyarakat.

\section{Kemudahan Mendapatkan pelayanan}

Ciri lain untuk menilai kualitas pelayanan ialah apakah pelayanan yang diberikan terhadap masyarakat memperoleh kemudahanatautidak (Dahri et al., 2017). Kemudahan memperoleh pelayanan yang dimaksudkan contohnya berapa banyak petugas yang melayani dan seberapa banyak dan baiknya fasilitas penunjang lainnya seperti komputer. Berdasarkan hasil pengabdian, dari sisi jumlah pegawai di Kantor Kelurahan Limo yang memberikan pelayanan terhadap masyarakat sudah sangat banyak, ditambah dengan pegawai honorer yang ada di Kantor Kelurahan Limo. Berdasarkan hasil penjelasan menggambarkan bahwa untuk mendukung pelaksanaan pelayanan pada masyarakat di Kantor Kelurahan Limo, jumlah pegawai baik PNS maupun tenaga honorer telah cukup.

Terkait dengan kemudahan untuk mendapatkan pelayanan dari segi banyaknya fasilitas penunjang seperti komputer di Kantor Kelurahan Limo, menurut hasil pengabdian bahwa jumlah sarana berupa komputer belum cukup untuk melayani banyaknya kebutuhan masyarakat yang seharusnya dilayani, apabila kita mengharapkan pelayanan yang cepat. Apalagi jika sarana komputer tersebut tibatiba rusak, tentu pelayanan terhadap masyarakat akan menjadi terhambat. Berdasarkan hasil pengamatan di lapangan mengenai kualitas pelayanan di kantor Kelurahan Limo, bila ditinjau dari segi jumlah pegawai yang melayani masyarakat sudah cukup, hanya dari segi disiplin pegawai yang perlu ditingkatkan supaya kemudahan mendapatkan pelayanan sesuai yang diharapkan bisa tercapai. Dari segi fasilitas kantor seperti komputer masih perlu ditambah jumlahnya supaya pelayanan yang optimal dapat dicapai.

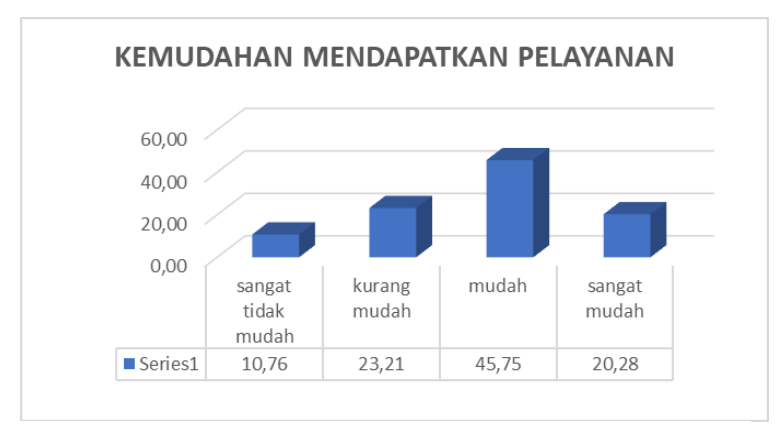

Gambar 9. Indikator Kemudahan Mendapatkan Pelayanan Sebelum Pelatihan

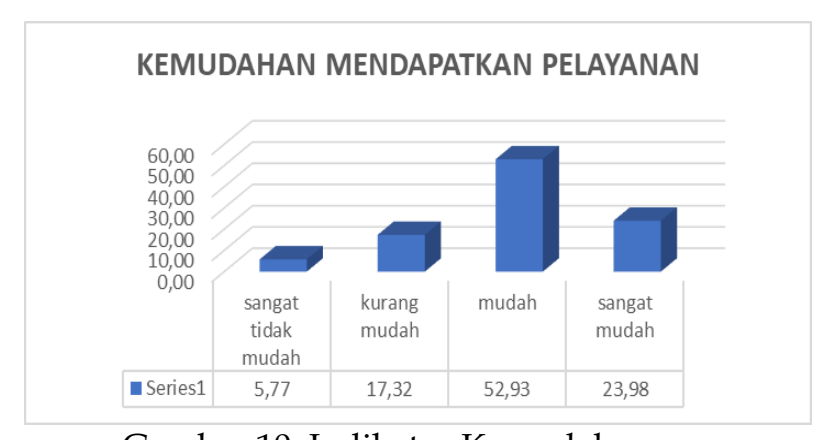

Gambar 10. Indikator Kemudahan Mendapatkan Pelayanan Setelah Pelatihan

Dari gambar 9 dan 10 terlihat bahwa indikator kemudahan mendapatkan pelayanan aparat Kelurahan Limo mengalami peningkatan setelah adanya pelatihan, mereka lebih disiplin dan datang lebih tepat waktu, sehingga bisa memberikan pelayanan kepada masyarakat lebih awal. Namun sarana pendukung komputer belum bisa direalisasikan dalam waktu dekat terkait dengan belum adanya anggaran pembelian komputer baru. 


\section{Kenyamanan Dalam Memperoleh Pelayanan}

Kenyamanan dalam mendapatkan pelayanan terkait dengan lokasi, ruang tempat pelayanan, tempat parkir, ketersediaan informasi pendukung dan lain-lain. Terkait lokasi Kantor Kelurahan Limo, sesuai dengan hasil pengabdian bahwa, lokasi kantor Kelurahan Limo sangat strategis sebab berada di tengah kota Limo. Letak kantor ini sangat memudahkan masyarakat untuk menjangkaunya. Hal ini sangat mempermudah masyarakat untuk dating berurusan segala keperluannya. Hal tersebut didukung dengan hasil wawancara pengabdi yang menggambarkan bahwa lokasi kantor Kelurahan Limo sangat strategis, karena letaknya berada di tengahtengah kota Limo. Dengan demikian, akses untuk mendapatkan pelayanan dari segi jarak amat dekat dari semua lingkungan yang ada di Kelurahan Limo.

Berkaitan dengan ruang tempat pelayanan di kelurahan Limo, sesuai dengan hasil observasi pengabdi di kantor Kelurahan Limo, pengabdi melihat bahwa masih perlu dilakukan penambahan ukuran luas ruangpelayanan. Dimana ruangan pelayanan yang ada saat ini sangat terasa sempit jika masyarakat banyak yang datang mengurus keperluannya di Kantor Kelurahan Limo. Ruang tempat pelayanan yang ada di kantor Kelurahan Limo dari segi luas, amat tidak representative untuk ukuran tempat pelayanan publik, karena semakin banyaknya masyarakat yang harus dilayani.

Berkaitan dengan kenyamanan dalam memperoleh pelayanan yang berkaitan dengan tempat parker menurut hasil pengabdian bahwa, lokasi halaman Kantor Kelurahan Limo yang cukup memudahkan masyarakat untuk memakirkan kendaraannya apabila dating berurusan di Kantor Kelurahan Limo. Namun belum ada tempat khusus dibuatkan untuk tempat parkir yang aman bagi masyarakat yang berkendara. Tentu saja hal ini akan mengganggu masyarakat apabila tiba-tiba hujan turun, karena kendaraan akan terkena hujan.

Saat ini belum ada tempat parkir khusus untuk kendaraan yang disiapkan di kantor Kelurahan Limo, ini menjadi keluhan masyarakat yang datang berurusan di Kantor Kelurahan Limo, karena masyarakat menginginkan adanya tempat parkir khusus agar kendaraan tidak terkena panas matahari atau pun hujan.

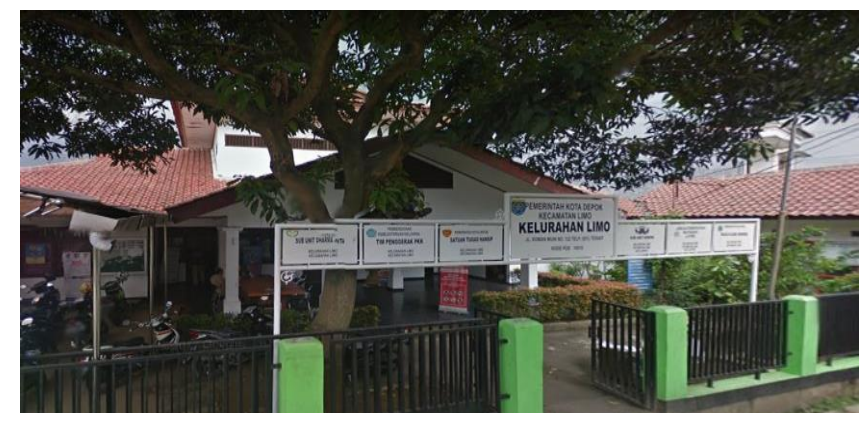

Gambar 11. Halaman depan Kelurahan Limo

Terkait dengan kenyamanan dalam mendapatkan pelayanan, dalam hal ini ketersediaan informasi di Kantor Kelurahan Limo, menurut hasil pengabdian, bahwa umumnya masyarakat menginginkan prosedur pelayanan yang mudah supaya mereka dengan cepat mendapatkan pelayanan yang diinginkan. Persoalan ini 
tentunya berkaitan erat dengan ketersediaan papan yang seharusnya disiapkan oleh pihak kantor Kelurahan Limo. Namun pengabdi tidak menemukan adanya papan informasi yang tersedia di kantor Kelurahan Limo.

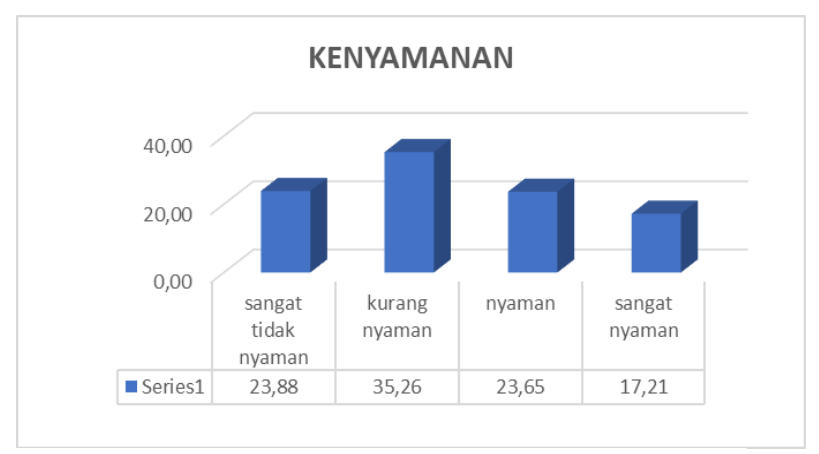

Gambar 12. Indikator Kenyamanan Dalam Memperoleh Pelayanan Sebelum Pelatihan

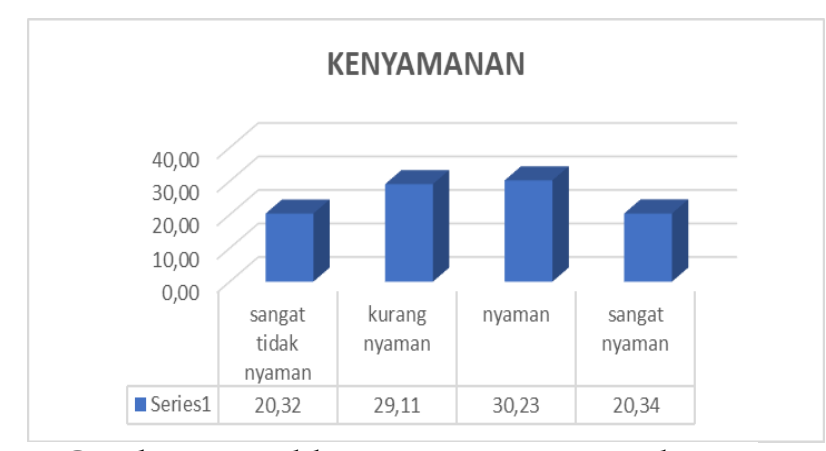

Gambar 13. Indikator Kenyamanan Dalam Memperoleh Pelayanan Setelah Pelatihan

Dari gambar 12 dan 13 terlihat bahwa indikator kemudahan mendapatkan pelayanan aparat Kelurahan Limo mengalami peningkatan setelah adanya pelatihan, namun peningkatan ini tidak terlalu signifikan, hal ini disebabkan tidak mudahnya menyiapkan sarana prasarana yang dibutuhkan karena terkait dengan anggaran yang ada. Setelah kami melakukan pengabdian di sana, Kelurahan Limo belum bisa untuk memperluas tempat pelayanan disebabkan area Kantor Kelurahan yang sudah padat dengan perumahan penduduk. Tempat parkir juga belum bisa ditutup dengan kanopi sehingga motor yang parkir masih kehujanan dan kepanasan. Ketersediaan informasi sudah mengalami peningkatan, ada leaflet- leaflet yang dipasang yang dapat memberikan informasi kepada masyarakat.

\section{Atribut Pendukung Lainnya.}

Ciri lain yang menentukan baiknya kualitas pelayanan publik ialah adanya atribut pendukung lainnya seperti ruang tunggu berAC, kebersihan dan sebagainya. Menurut hasil pengabdian di Kantor Kelurahan Limo, pengabdi mengamati bahwa di Kantor Kelurahan Limo telah tersedia ruang pelayanan yang ber-ac, namun pada siang hari ruangan kantor masih terasa panas sebab AC yang ada masih kecil kapasitas pendinginnya sehingga mempengaruhi kenyamanan masyarakat dalam memperoleh pelayanan. Dari sisi atribut pendukung lainnya seperti sarana toilet di kantor Kelurahan Limo dapat pengabdi gambarkan bahwa saat ini belum tersedia untuk masyarakat umum, sehingga menyebabkan ketidaknyamanan masyarakat dalam mendapatkan pelayanan.

Dari sisi kebersihan baik dalam ruangan kantor ataupun di luar kantor Kelurahan Limo selalu terjaga kebersihannya. Hal ini tentu menjadi kredit point bagi Kantor Kelurahan Limo dan suasana ini senantiasa dipertahankan bahkan ditingkatkan di kemudian hari agar kenyamanan masyarakat yang memerlukan pelayanan dapat tercapai. Tantangan kemudian bagaimana masyarakat yang datang mengurus kebutuhan surat-surat di kantor Kelurahan Limo senantiasa diberikan pemahaman atau penjelasan agar secara bersama-sama dengan pihak Kelurahan Limo dapat 
menjaga kebersihan baik dalam ruangan kantor maupun diluar kantor. Dari hasil kuesioner yang diberikan kepada warga masyarakat yang menggunakan layanan Kelurahan Limo, hasil pendapat mengenai atribut pendukung layanan seperti pada histogram berikut ini:

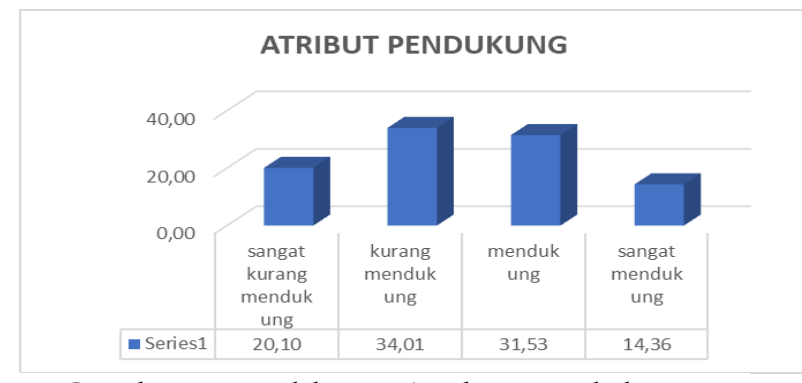

Gambar 14. Indikator Atribut Pendukung Sebelum Pelatihan

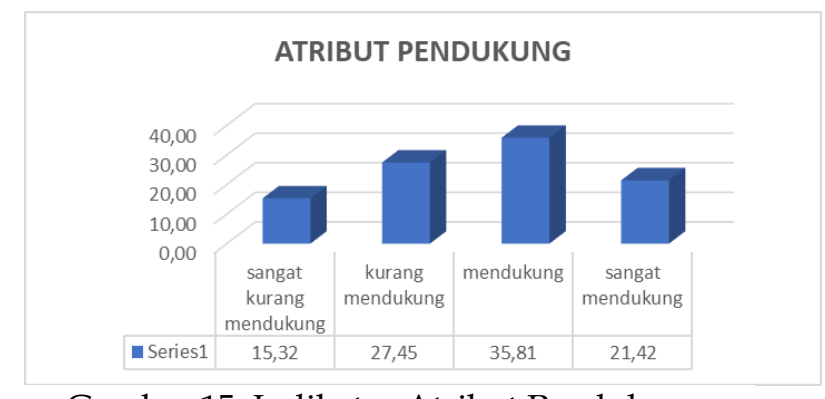

Gambar 15. Indikator Atribut Pendukung Setelah Pelatihan

Dari gambar 14 dan 15 terlihat bahwa indikator atribut pendukung pelayanan aparat Kelurahan Limo mengalami peningkatan setelah adanya pelatihan.

\section{Simpulan Dan Rekomendasi}

Berdasarkan pada pemaparan dalam pembahasan dari hasil pengabdian di lapangan, maka pengabdi dapat menyimpulkan bahwa kualitas pelayanan yang diberikan aparat Kelurahan Limo mengalami peningkatan kualitas sesuai dengan harapan masyarakat setelah mengikuti pelatihan peningkatan kualitas pelayanan aparat Kelurahan, hal ini nampak pada masalah: ketepatan waktu, yakni waktu proses dimana aparat Kelurahan Limo dapat memberikan pelayanan kepada masyarakat dengan baik sesuai dengan jam kerja pegawai yang dimulai pukul 07.30 sampai dengan 16.00. Akurasi pelayanan, dimana aparat Kelurahan Limo dalam memberikan pelayanan kepada masyarakat lebih berhati - hati dan teliti sehingga tidak banyak terjadi kesalahan. Kesopanan dan keramahan kepada masyarakat, dimana aparat Kelurahan Limo memiliki sikap sopan dan ramah kepada masyarakat yang mendapatkan pelayanan. Hal ini tergambar suasana keakraban antara aparat kelurahan dengan masyarakat. Kemudahan mendapatkan pelayanan, dari segi banyaknya petugas yang melayani. Dimana saat ini pegawai di Kantor Kelurahan Limo sudah banyak, hanya diperlukan penambahan komputer, dimana fasilitas tersebut masih dirasakan kurang dan masih perlu ditambah untuk mendukung kemudahan dalam memberikan pelayanan kepada masyarakat. Kenyamanan dalam memperoleh pelayanan yang berkaitan dengan lokasi tepat kantor Kelurahan Limo yang sangat strategis tempatnya atau lokasinya. Kenyamanan dalam memperoleh pelayanan yang berkaitan tempat pelayanan, tempat parkir, ketersediaan informasi dan lain-lain, dimana masih perlu perbaikan-perbaikan agar kenyamanan dalam memberikan pelayanan sesuai dengan harapan masyarakat. Atribut pendukung lainnya seperti ruang tunggu yang ber AC, kamar mandi untuk umum dan lain-lain, dimana sarana tersebut belum memadai. 
Sesuai dengan kesimpulan maka rekomendasi yang dapat disampaikan yaitu: perlu ada upaya atau tindakan terhadap pegawai yang tidak disiplin dalam menjalankan tugas, karena sangat merugikan negara dan masyarakat. Perlu adanya bimbingan atau pelatihan kepada pegawai di Kantor Kelurahan Limo, dalam rangka meningkatkan sumber daya manusia yang berkualitas. Pihak Pemerintah Kelurahan Limo perlu melakukan pembenahan dan mengusulkan kepada Pemerintah Daerah agar melakukan penambahan beberapa fasilitas kantor, seperti ruangan dan fasilitas pendukung lainnya seperti komputer, AC dan lain-lain yang menunjang kelancaran aktivitas pelayanan. Demikian pula halnya tempat parkir khusus kendaraan. Sesuai dengan keseluruhan pemaparan dari ke enam ciri yang menentukan kualitas pelayanan di atas yang dijadikan tolok ukur untuk mengevaluasi kualitas pelayanan publik agar memenuhi kepuasan masyarakat, maka dalam pengabdian ini sangat mendukung dan membantu aparat Kantor Kelurahan Limo meningkatkan kualitas pelayanan kepada masyarakat.

\section{Daftar Pustaka}

Bawole, D. S., Lengkong, F. D., \& Kiyai, B. (2015). Faktor-Faktor Yang Mempengaruhi Kualitas Pelayanan Publik Pada Kantor Kelurahan Bahu Kecamatan Malalayang Kota Manado. Jurnal Administrasi Publik, 4(32).

Dahri, J., Paranoan, D. B., \& Idris, A. (2017). Kinerja Aparatur pada era Pelaksanaan Pelayanan Administrasi Terpadu Kecamatan (Paten) di Kantor Camat Sangasanga Kabupaten Kutai Kartanegara. Jurnal Administrative Reform (JAR), 2(3), 433-444.

Gamal, M. S. (2018). Analisis Kualitas Pelayanan Di Kantor Kelurahan Pasangkayu Kabupaten Mamuju Utara. Katalogis, 6(2).

Kusuma, A. C., \& Suflani, S. (2019). Analisis Kualitas Pelayanan Publik Dengan Metode Servqual (Service Quality) (Studi Kasus pada Kantor Kelurahan Tembong Kota Serang). Jurnal Manajemen STIE Muhammadiyah Palopo, 5(2).

Mahsyar, A. (20). Masalah Pelayanan Publik di Indonesia dalam Perspektif Administrasi Publik. Otoritas: Jurnal Ilmu Pemerintahan, 1(2).

Malau, H. (2010). Menyoal Pelayanan Publik yang Berkualitas di Era Otonomi Daerah. Jurnal Demokrasi, 8(1).

Malik, M. (2018). Penyuluhan Peningkatan Kualitas Pelayanan Publik Di Desa Kelawi Kecamatan Bakauheni Kabupaten Lampung Selatan. Pengabdian Kepada Masyarakat.

Maryam, N. S. (2016). Mewujudkan Good Governance Melalui Pelayanan Publik. Jurnal Ilmu Politik Dan Komunikasi: Politeknik Kridatama Bandung.

Pertiwi, A., Tasya, S. N., Rahadian, I. A., \& Si, M. (2017). Reformasi Birokrasi Dalam Pelayanan Publik.

Purwadi, P. (2019). Analisis Kualitas Pelayanan Di Kantor Kelurahan Padasuka Kecamatan Cimenyan Kabupaten Bandung. Ensains Journal, 2(2), 3-9. 
Rochmah, S. (2018). Analisis Reformasi Pelayanan Publik Di Indonesia.

Sá, F., Rocha, Á., \& Cota, M. P. (2016). Potential Dimensions For A Local EGovernment Services Quality Model. Telematics and Informatics, 33(2), 270-276.

Safira, A. P. (2020). Makalah Etika Aparatur Dalam Memberikan Pelayanan Publik.

Spears, L. C., \& Lawrence, M. (2016). Practicing Servant-Leadership: Succeeding Through Trust, Bravery, And Forgiveness. John Wiley \& Sons.

Ugaddan, R. G., \& Park, S. M. (2017). Quality Of Leadership And Public Service Motivation. International Journal of Public Sector Management.

Wahid, A. (2017). Reformasi Pelayanan Publik di Indonesia. Jurnal TAPIs, 14(1), 1-10. 